\title{
The Perfect Storm and the Privatization of Public Higher Education
}

by

Ronald G. Ehrenberg

(Forthcoming in Change,November 2005)

Ronald G. Ehrenberg is Irving M. Ives Professor of Industrial and Labor Relations and Economics at Cornell University and director of the Cornell Higher Education Research Institute (CHERI). CHERI is financially supported by the Andrew W. Mellon Foundation, the Atlantic Philanthropies (USA) Inc., and the TIAA-CREF Institute. However, the views expressed here are solely his own.

\section{The Perfect Storm}

During the last quarter of a century, public higher education institutions have found themselves buffeted by a perfect storm (a term I owe to Pat Callan). This storm has led to discussions about the privatization of those institutions, which has implications for their ability to improve, or at least maintain, their quality and their accessibility to students from all socioeconomic backgrounds. A weakening of our public higher education system along either the quality or accessibility dimension would have serious implications for our nation’s future.

What are the factors led to this perfect storm? Following the Reagan revolution in the 1980s, which reduced the value of the state income tax deduction on federal income tax returns, taxpayers clamored for state income tax cuts. But since then, increased state funding needs for Medicaid, elementary and secondary education, and the criminal justice system have put increasing pressure on state tax revenues. The consequence has been structural deficits in many state budgets. There simply have not been sufficient revenues available to fund public higher education generously, and dramatic reductions in the share of state budgets devoted to higher education have taken place. 
Since these pressure on state coffers were mounting just when enrollments in public higher education institutions were rapidly increasing (from under 8 million in 1974 to over 12 million in 2004), it is perhaps remarkable that average state appropriations per full-time equivalent student at public higher education institutions have increased, on average, at an annual rate that has exceeded the rate of increase in consumer prices by about 0.6 percent a year (or remained almost flat if inflation is calculated not by the Consumer Price Index but according to the more realistic Higher Education Price Index). Given that state support for public higher education is one of the few real discretionary categories in state budgets and higher education is one of the few state agencies that charges for its services, policymakers seem to have concluded that flat funding is all that public higher education can expect from the state. Real increases will have to be provided by tuition.

Traditionally public higher education has been viewed as a social good that yields benefits to the nation as a whole. But as earnings differences between highly educated and less educated individuals have widened, and the private economic return higher education provides its students has grown, policymakers have concluded that those students and their families should pay a greater share of the costs of public higher education. (See David Longanecker's article in this issue for a more extensive discussion of policymakers' attitudes.)

During the same period, however, the private colleges and universities were raising their tuitions at a rate of over three percent above inflation. In an effort to remain competitive, public higher education institutions raised their tuition annually at roughly equivalent rates. But because public tuitions started at a much lower level, the actual 
dollar increases the publics netted from these increases have been much lower. Moreover, privates with large endowments benefited greatly from the run up in stock market prices that took place during the 1990s.

As a result, expenditures per student at the publics have fallen relative to those at the privates. During the 20 years ending in 1995-96, expenditures per student (adjusted for inflation) rose by 52 percent at private four-year institutions and by 40 percent at private four-year institutions. Average expenditures at public four-year institutions that were about 78 percent of the level at their private counterparts in 1975-76 fell to 72 percent by 1995-96. Due to changes in accounting rules, expenditure-per-student data have not been published for private colleges and universities since 1995-1996, but the percentage is undoubtedly much lower today.

As a result, faculty salaries at public universities have fallen relative to those at private universities. Data from the American Association of University Professors' annual survey indicate that between 1978-79 and 2003-2004, the average salary of full professors in public doctoral institutions fell from 91percent to 78 percent of the average salary of full professors in the privates. This has made it difficult for the publics to attract and retain top faculty. During that same period, student/faculty ratios at public universities rose relative to those at private universities. Using IPEDs data, Thomas Kane and Peter Orzag calculate that between 1971 and 1997, the number of full-time equivalent students per faculty member fell at private research universities from 17.3 to 15.7 while it rose slightly at public research universities from 21.1 to 21.7.

Resource constraints have led public colleges and universities, more than their private counterparts, to substitute part-time and full-time non-tenure-track faculty for 
tenured and tenure-track faculty. For example, during the decade of the 90s alone, the percentage of undergraduate credit hours taught by tenured and tenure-track faculty fell by over 22 percentage points at the four State University of New York university centers. Research that I conducted with Liang Zhang of the University of Minnesota suggests that these types of substitution have a negative effect on undergraduate students' graduation rates and first-year drop-out rates, with the largest impacts at the four-year public comprehensive institutions. We found that for those institutions, a ten-percentage point increase in part-time faculty is associated with a three-percentage point reduction in the five-year graduation rate, while a ten-percentage point increase in full-time faculty in non-tenure-track positions is associated with a reduction of 4.4 percentage points in the graduation rate, all things being equal.

As public tuition levels have increased and a greater share of public higher education costs have been shifted to students and their families, states and the federal government have responded to political pressure from the middle class by shifting financial aid away from need-based aid. At the state level, a greater share of funding is now in the form of grant aid to students rather than appropriations to public institutions to support their operations. And that aid is increasingly based on merit, which privileges educationally advantaged students.

By 2003, 13 mostly Southern states had introduced broad-based merit-aid programs modeled on Georgia’s Hope Scholarship and, like it, designed to encourage high school graduates to attend in-state academic institutions. Susan Dynarski calculates that in many of these states, the 30 percent or more of high school graduates who qualify for these awards are disproportionately white and middle- or upper-income. Hence the growth of 
these programs can be understood primarily as a response to large voting blocs concerned about rising college tuitions, not as an effort to increase access for underrepresented groups.

At the federal level, the major growth in financial aid has been in loans and tax credits for college attendance, not increases in the level of Pell grant awards. And massive federal deficits, both now and projected for the future -- caused by recent reductions in federal tax rates, increases in military expenditures (at least in the short run,) and the growing need to worry about future Medicare and Social Security trust fund deficits -- make it unlikely that the federal government will be a future source of revenue to shore up our nation's public higher education system through substantial increases in need-based grant aid to students.

So increasingly, providing grant aid to maintain access to public higher education is becoming the responsibility of the public higher education institutions themselves.

\section{Can Privatization Work?}

While privatization policies have arisen at least partially from the budget problems that states face, as well as from policymakers' willingness to shift the costs of higher education from taxpayers to students, they also arise from the view that forcing the publics to behave more like the privates and compete for resources will lead to increased efficiencies and the elimination of waste. Meanwhile, as state support becomes an increasingly smaller proportion of their budgets, many public institutions want to be freed from governmental constraints that lead to inefficiencies in their operations and to have 
the freedom to make economic decisions that will improve their ability to compete with the privates.

The most important of these is the freedom to raise tuition to market levels. In the past, public universities typically raised their resident undergraduate tuition substantially only when state appropriations were cut during a recession, in order to partially offset the effects of the state cuts. But when they did, state legislatures and governors took the heat, thus generating political pressure to limit future tuition increases or even to roll back previous increases, as happened in Virginia and California in recent years.

Whether making formal agreements with the state to trade some level of state support for tuition control gives the publics more freedom is an open question. For example, Miami University of Ohio moved to a high-tuition policy in the fall of 2004, charging resident and nonresident students the same tuition but promising each resident undergraduate student a grant at least equal to the state appropriation per student that it received. However, Miami’s proposed increase in undergraduate tuition of nine percent for fall 2005 was vetoed when the legislature and the governor capped resident tuition increases at six percent or $\$ 500$, whichever was less. In Miami’s case, it was $\$ 500$, which translated into a 5.5 percent resident tuition increase.

Privatization policies vary widely and depend upon the specific circumstances of the state. For example, constitutional limitations on the growth of state expenditures, from which grants to students were exempt, convinced administrators of the University of Colorado system that they were better served by giving up much of their state appropriation in return for accepting a system in which students would receive vouchers that could be used to partially offset tuition payments at state institutions. Inasmuch as 
the initial level of these vouchers was less than the cut in state appropriations per student that the university faced, they university had to negotiate a substantial increase in tuition as well. (See the James Jacobs article in this issue for more about the Colorado experiment.)

Or to take another example, the Virginia General Assembly recently adopted legislation that grants public institutions additional authority over financial and administrative operations (including the freedom to raise tuition, within limits), but only after they make certain commitments to the state and only with appropriate accountability. Three levels of autonomy are available to institutions, depending upon their financial strength and management structure. (See Gov. Mark Warner and Peter Blake's article in this issue for a discussion of the Virginia plan.)

In judging the likely success of privatization efforts, it is important to understand how undergraduate and graduate education expenditures are financed. At private colleges and universities, the three largest source of revenue are net tuition (tuition minus grant aid), endowment income, and annual giving. Public institutions have these three sources plus state appropriations.

Although the extra source of revenue would seem to advantage the publics, it does not. If state appropriations (or the vouchers that substitute for them) fail to grow or are cut back, a greater share of public institutions' educational funding must come from net tuition growth and increases in endowment income and annual giving. But while some flagship public institutions have substantial endowments and annual-giving levels, most do not. As John Wiley - the chancellor of the University of Wisconsin-Madison -- has shown, most of them are unlikely to be able to generate the endowment and annual- 
giving levels that would be necessary to compensate for reductions in their state support. Hence while aggressively seeking increased endowments and annual giving may help, public higher education institution trying to compensate for declining state support will have to devote most of their efforts to increasing their net tuition revenues.

The key work here is net. Increasing tuition by a given percentage does not guarantee that the total revenues generated by the tuition increase will increase by the same percentage, since a portion of those revenues goes to student aid, otherwise known as tuition discounts. Preliminary results from the 2004 annual NACUBO Tuition Discounting study suggest that freshman tuition discount rates average 38.6 percent at private colleges and universities in the United States, ranging from 41.1 percent at lowtuition smaller colleges to 30.5 percent at the larger private universities. Moreover, save for a few highly selective private colleges and universities, these tuition discounts are not based solely on need but often on merit. Institutions use aid to boost their position on the prestige hierarchy by crafting a class with the desirable characteristics of high test scores and low need.

Flagship public universities have far more applicants than they have positions in their first-year student bodies. So large tuition increases are unlikely to leave them with unfilled seats. What they do have to worry about is maintaining the selectivity of their undergraduate student bodies, since large tuition increases may make private competitors seem more attractive to many of their top applicants who do not have financial need. Hence a share of the extra tuition revenues that the public institutions receive from substantially increasing tuition would most certainly be directed towards merit-based scholarships. Given all the other uses that they have for the extra tuition revenues as well 
(for example, building back full-time faculty size and increasing faculty and staff compensation), they may or may not have generated the necessary extra institutional funds to compensate for decreased appropriations once they hit their market limits on the price of tuition.

Nevertheless, the flagships are the public institutions that will prosper the most from moving to a high tuition/low state appropriations model, because the demand for their seats is likely to be much less sensitive to price than for those at the public comprehensives, which already admit a high percentage of their applicants. Attempts to raise tuition substantially there may well result in lower enrollments and less net tuition coming in, as some potential students instead enroll in private four-year or public twoyear colleges or simply fail to enroll in college at all.

It is absolutely essential that the public flagships remain accessible to students from lower- and lower-middle income families. But data on the share of Pell Grant recipients among the undergraduate student bodies at our nation's major public universities suggests that a number of these institutions already enroll relatively few students from these groups (some flagships, such as the University of California campuses, are notable exceptions). For example, Donald Heller has estimated that in 2001-2002 Pell Grant recipients were 19 percent of the undergraduate student bodies at our nation's most selective public universities, whereas they were about 27 percent of the undergraduate student bodies nationally at four-year public institutions.

With privatization, we run the risk of public higher education's coming even more stratified, with upper- and upper-middle-income students studying at relatively wellfunded flagship campuses and lower- and lower-middle income students studying at less 
well-funded public comprehensive institutions and two-year colleges. The flagships will have not only more room to raise tuition but a much greater ability to increase their other sources of revenue (such as endowments, annual giving, indirect costs on research grants, and revenues from commercialization of research findings). Large funding differentials already exist between these institutions, and they will get worse. For example in 20012002, instructional expenditures per full-time student averaged $\$ 9,673$ at public flagship (doctoral-extensive) campuses, $\$ 4,903$ at public comprehensive institutions, and $\$ 3,979$ at public two-year colleges. And having access to the flagships makes a long-term difference to students: Research has shown that those who attend better-funded institutions have higher earnings after graduation.

Such increasing stratification is not socially desirable. Any "compact” to allow the public flagships to increase their tuition levels substantially must include a commitment to ensure that they are accessible to students from throughout the spectrum of family incomes. Examples of public flagships that already have undertaken such commitments are the University of North Carolina Chapel Hill, with its "Carolina Covenant," and the University of Virginia, with its “Access UVA” program. Both programs guarantee that students from families with incomes less than twice the federal poverty level can attend the institution without incurring any debt. Both programs include comprehensive efforts by the universities to recruit more students from lower-income families and, in the case of Virginia, a promise to report to the state each year on the socioeconomic distribution of its student body. 


\section{Public Higher Education is More than Undergraduate Education}

Advocates of privatization of public higher education assume that cutbacks in state support can be made up by increases in tuition paid by students who will reap the economic return from their investments in education. This is at least partially true for undergraduate education and for graduate programs that train students for professional careers. But high tuition levels coupled with the need to take out loans may well discourage students from majoring in lower-paying fields that are important to society, such as education, social work and nursing. If tuitions do increase sharply at public higher education institutions, it will be incumbent upon states to develop or expand scholarship or loan-forgiveness programs for graduates of their public institutions who remain in the state after graduation and work in fields deemed to be important to the state.

Most doctoral students at major American universities are supported by their institutions on fellowships, research assistantships, and teaching assistantships, all of which typically provide for tuition remission. Funds for these forms of support at public universities come largely from federal research grants and state appropriations. It will be difficult to make up for cutbacks in state support for doctoral education by raising graduate tuition levels. Faculty with external research grants that cover tuition for graduate students will suddenly see the real value of their grants reduced, and tuition remission for teaching assistants reduces institutional net revenue.

So absent raising tuition for undergraduate still further to subsidize the cost of doctoral education, a politically and morally unpalatable move, reduced state support for public higher education will lead to less well-funded doctoral students. This will reduce 
the attractiveness to top American undergraduates of doctoral study at the public universities and adversely affect the quality of the graduate students who are serving as teaching assistants at those institutions, which in turn will adversely affect the quality of undergraduate education.

Doctoral students are an important input into research at the public universities. Fewer and lower-quality students will reduce the quantity and quality of the research that is produced at there. Studies suggest that the level of research conducted at a university affects the level of innovation and economic growth in the area surrounding it. Most state support for research that public universities receive takes the form of lower teaching loads for faculty to allow them more time for research. If less state support for research is translated into higher teaching loads for faculty (and fewer faculty), this will not only reduce their research productivity but further increase the difficulty that the public flagships have in attracting and retaining high-quality faculty.

Public institutions, especially the land grants, have an obligation to serve the population of the entire state, not just the students attending the institutions. Through agricultural, consumer, and industrial extension services, these institutions have been major transmitters of knowledge to American farmers, consumers, workers, and industry. Cutbacks in state appropriations for the extension and land-grant activities of the institutions have forced these operations to become more entrepreneurial. They can use the "profits" from groups that can pay (e.g. large corporations) to subsidize the provision of services to underserved populations, services that were previously financed by the state. However, forced to generate their own revenues, it is natural for extension services 
to spend a greater share of their time on commercial activities and less on serving the public at large.

More generally, public higher education benefits many more citizens of the state than those attending the institutions or those directly receiving services from the extension activities of the institutions. Research indicates there is a social return to higher education that includes increased income for non college graduates, increased state tax revenues, increased intergenerational mobility, and lower welfare costs. If a high-tuition policy for public higher education reduces the fraction of the population going on to and completing college, we will all be worse off.

\section{Looking to the Future}

Privatization may help the most competitive flagship public universities obtain the resources they need to compete with their private-sector counterparts and regain their quality, but special efforts will be required to make sure that they continue to enroll students from lower and middle-income families. Privatization is much less likely to be a viable strategy for our nation's public comprehensives and two-year colleges, and that is where our primary concern about reductions in state support should lie.

Economists and higher education finance specialists are not known for their accuracy in making long-run forecasts about higher education. During the 1970s many predicted that public colleges and universities would prosper relative to the private counterparts in the years ahead, and as I have shown, these predictions were not correct. However, these scholars do understand the role that incentives play. 
Thomas Kane and King Alexander, among others, have been struck by how asymmetrical the incentives in federal public policy are with respect to state Medicaid and state higher education expenditures. Through matching formulae, a state that spends more on Medicaid is rewarded with more federal matching funds, whereas a state that reduces its Medicaid expenditures sees its federal funding diminish. In contrast, when a state spends less on its public higher education institutions and the institutions respond by increasing tuition, the level of Pell Grant funds received by the residents of the state goes up. So in tough times, a state gains revenues by protecting its Medicaid expenditures rather than appropriations to its public colleges and universities.

Regardless of one's political persuasion and one's perspectives on the desirability of privatization, most people would probably conclude that at least the incentives in federal public policy for states to spend more on higher education should be symmetrical to the incentives for them to spend more on Medicaid. Developing federal policies that reward states for spending more, rather than less, on their public higher education institutions and for spending more on need-based financial aid would go a long way to improving the quality and accessibility of our nation's public higher education system.

\section{$\underline{\text { Resources }}$}

Susan Dynarski, “The New Merit Aid” in Caroline Hoxby ed. College Choices: The Economics of Where to Go, When to Go, and How to Pay for It (Chicago IL: University of Chicago Press, 2004): 63-97 
Ronald G. Ehrenberg, “Graduate Education, Innovation and Federal Responsibility, Communicator (July 2005) (available at www.cgs.edu)

Ronald G. Ehrenberg and Liang Zhang, "Do Tenured and Tenure-Track Faculty Matter?” Journal of Human Resources (forthcoming) (available at www.ilr.cornell.edu/cheri )

Ronald G. Ehrenberg and Michael J. Rizzo, "Financial Forces and the Future of American Higher Education”, Academe 90 (July/August 2004): 25-31

Donald E. Heller, “Pell Grant Recipients in Selected Colleges and Universities” in Richard Kahlenberg Ed. America's Untapped Resource: Low Income Students in Higher Education (New York, NY: The Century Foundation, 2004)

Thomas J. Kane and Peter R. Orszag, “Funding Restrictions at Public Universities: Effects and Policy Implications” (Washington DC: Brookings Institution Working Paper, September 2003)

Michael J. Rizzo, “The Public Interest in Higher Education”, Cornell Higher Education Research Institute Working Paper No. 55 (November 2004) (available at www.ilr.cornell.edu/cheri )

John D. Wiley, "Higher Education at the Crossroads”, Madison Magazine (November 2003) (available at www.madisonmagazine.com) “2004 NACUBO Tuition Discounting Survey Preliminary Results”, NACUBO Business Officer (June 2005): 10-11 